University of Nebraska - Lincoln

DigitalCommons@University of Nebraska - Lincoln

Faculty Publications from the Harold W. Manter Laboratory of Parasitology

10-1972

\title{
Observations on Some Natural-Focal Zoonoses in Alaska
}

Robert L. Rausch

Arctic Health Research Center, rausch@u.washington.edu

Follow this and additional works at: https://digitalcommons.unl.edu/parasitologyfacpubs

Part of the Parasitology Commons

Rausch, Robert L., "Observations on Some Natural-Focal Zoonoses in Alaska" (1972). Faculty Publications from the Harold W. Manter Laboratory of Parasitology. 536.

https://digitalcommons.unl.edu/parasitologyfacpubs/536

This Article is brought to you for free and open access by the Parasitology, Harold W. Manter Laboratory of at DigitalCommons@University of Nebraska - Lincoln. It has been accepted for inclusion in Faculty Publications from the Harold W. Manter Laboratory of Parasitology by an authorized administrator of DigitalCommons@University of Nebraska - Lincoln. 


\title{
Observations on Some Natural-Focal Zoonoses in Alaska
}

\author{
Robert L. Rausch, PhD, Fairbanks, Alaska
}

\begin{abstract}
In Alaska, as in arctic and subarctic Eurasia, important natural-focal zoonoses are rabies, brucellosis, tularemia, trichinosis, alveolar hydatid disease, cystic hydatid disease, and diphyllobothriasis. Most frequently affected are aboriginal peoples in villages within biocenoses that include the natural parasite-host assemblages. Pathogens are transmitted to man from wild animals and from dogs, which are important as synanthropic hosts. The prevalence and rate of transmission of certain pathogens in natural foci are related to the numerical density of small mammals, especially rodents, which may themselves be involved as hosts, and on which the numbers of their predators ultimately depend, such as is evident in the natural cycles of Echinococcus multilocularis and of rabies virus. Some pathogens in northern regions exhibit biological characteristics that separate them from morphologically indistinguishable strains at lower latitudes (eg, Trichinella spiralis and $E$ granulosus). Host-parasite relationships may also differ, as in the Arctic where rabies virus is maintained in populations of foxes, without significant involvement of mammals of other groups. Faunal interchanges during and after the Pleistocene period have influenced the distribution of parasite-host assemblages in Alaska.
\end{abstract}

A is a landmass more than 1.5 million sq $\mathrm{km}$ in area, that lies mainly between $60^{\circ}$ and $70^{\circ} \mathrm{N}$ latitude, and is separated from Eurasia by the shallow waters of Bering Strait. During the last glacial phase, much of this land was part of a vast, unglaciated region that was bounded on the east by the continental ice sheet and extending westward into northeastern Siberia. Cold-adapted organisms, largely of Eurasian origin,

Submitted for publication Nov 22, 1971; accepted May 9, 1972.

From the Arctic Health Research Center, Public Health Service, Fairbanks, Alaska.

Read before the Second International Symposium on Circumpolar Health, Oulu, Finland, June 24, 1971.

Reprint requests to Infectious Disease Section, Arctic Health Research Center, Public Health Service, Fairbanks, Alaska 99701 (Dr. Rausch). evidently predominated in the unglaciated region (the Amphiberingian Refugium) at the end of the Pleistocene period. During postglacial time, elements of the residual palearctic fauna mixed with nearctic elements as species extended their ranges in North America following recession of the ice sheet. These interchanges must have affected the pattern of occurrence of natural-focal pathogens no less than they did the distribution of their vertebrate hosts. Some parasite-host assemblages in Alaska seem to have originated south of the continental ice sheet; others, of palearctic origin, exist under similar ecological conditions both in Eurasia and in northern North America.

A variety of ecological situations exists in Alaska. The phytogeographic divisions have not been precisely defined, but zones of tundra (as well as extensive treeless areas in the southwest), forest-tundra, and boreal coniferous forest, predominantly latitudinal although broken in pattern by the altitudinal effects of mountainous terrain, can be conveniently distinguished. The terrestrial mammalian fauna includes more than 40 species, of which at least 21 are considered to be holarctic. The avian fauna, which $\mathrm{em}$ braces a large component of panboreal species, is especially abundant with the arrival of migrants in spring; thereafter, high densities are found in wet lowlands, where Charadriiformes and Anseriformes predominate, and on sea cliffs, where alcids nest. Routes of migration of some species traverse north. eastern Eurasia as well as North America.

The invertebrate fauna includes many species that might serve as vectors of patho. genic organisms. Hematophagous Diptera of the families Culicidae, Simuliidae, and Tabanidae are abundant. Of about 30 species of mosquitoes, at least 23 are of the genus Aëdes; some occur abundantly and exten. sively. About 42 species of blackflies have been distinguished, of which 12 species of Simulium or Prosimulium feed on man. The 
tabanids include at least 25 species of four genera; species of Chrysops and Hybomitra attack man (K. M. Sommerman, personal communication, May 10, 1971).

Knowledge about the identity and distribution of the approximately 50 species of fleas (Siphonaptera) indigenous to Alaska has been acquired largely through the efforts of George P. Holland, PhD, of the Canada Department of Agriculture. About 35 species occur on mammals. Several holarctic species are known in North America only from Alaska, or from Alaska and adjacent areas of Canada. ${ }^{1}$

Four indigenous species of ticks are known. Ixodes uriae White and I signatus Birula are often numerous in sea bird colonies. Ixodes angustus Neumann, a holarctic species found south of the Alaska Range, is typically a parasite of rodents. The haretick, Haemaphysalis leporispalustris (Packard), periodically becomes abundant on varying hares, Lepus americanus Erxleben, in central Alaska. The extent of its geographic range in the north and west has not been defined. Little is known concerning parasitic mites; some holarctic species have been recorded from arvicoline rodents.

The occurrence of natural-focal zoonoses is influenced by many factors, including climate, terrain, vegetational patterns, and abundance and distribution of vertebrates. Transmission of such diseases to man often follows encroachment upon natural parasite-host assemblages. Some of the interrelationships that can be discerned for the better known zoonoses, namely rabies, brucellosis, tularemia, and alveolar hydatid disease, are briefly considered here.

\section{Viral Diseases}

Rabies is a prevalent disease of foxes in the holarctic zone of tundra, including the arctic islands and Greenland.2 Our data on the occurrence of rabies in wild mammals in Alaska are based upon demonstration of the virus in suspected rabid animals submitted to the laboratory and in ostensibly normal animals collected at random. During the 22-year period ending with April 1971, we recorded the virus in wild mammals of four species: red fox, Vulpes vulpes L; arctic fox, Alopex lagopus $\mathrm{L}$; wolf, Canis lupus $\mathrm{L}$; and reindeer (caribou), Rangifer tarandus L. However, the data presented here concern mainly the findings of the past 12 years, during which more adequate communications have facilitated collection of specimens and information.

From January 1958 to May 1971, a total of 1,521 wild mammals was tested for rabies. Positive results were obtained in 100 of 306 red foxes, and in 170 of 898 arctic foxes. Among 317 animals representing 15 additional species, the virus was demonstrated only in two wild reindeer and three wolves. During the same period, one domestic reindeer, $45 \mathrm{dogs}$, and one domestic cat were found to be rabid.

The animals in which rabies virus was identified originated mainly within the treeless regions of northern and western Alaska and on St. Lawrence Island in the Bering Sea (Fig 1). The lack of records of infected foxes in northern Alaska during three of the last 12 years is probably attributable to the absence of observers in this sparsely settled region and to the unconcern often demonstrated by the Eskimos toward rabid foxes. On St. Lawrence Island, the disease appears to have occurred annually. In contrast, in the treeless regions farther south, on the lower Alaska Peninsula, the outbreak in the winter of 1970 to 1971 was the first recorded in ten years.

The records indicate that the frequency of outbreaks in foxes decreased from north to south, and that the prevalence in foxes decreased inversely with the degree of regularity in the periodicity of fluctuations in numbers of arvicoline rodents (ie, voles and lemmings). However, as indicated by observations on the arctic slope, where the cyclic pattern of fluctuations in numbers of brown lemmings, Lemmus sibiricus Kerr, is most strongly defined, no direct correlation could be discerned between numbers of the rodents and occurrence of rabies (Fig 2).

The preponderance in winter of records of rabies virus from foxes of the two species seems clearly to be correlated with the annual cycle of these mammals (Fig 3 and 4). At high latitudes, populations of foxes attain maximum densities in late summer and early autumn, with dispersal of young animals from the dens. The increased density and the tendency of the foxes to congregate around sources of food (eg, carcasses of marine mammals) contribute to frequent intraspecific contact that furthers transmission of the virus. The increasing prevalence of the disease in winter appears to be a consequence of a geometric pattern of transmission that begins in early autumn. In spring, when the surviving foxes scatter and occupy dens, transmission of the virus is inhibited.

The wide variation in length of the incubation period ensures that some infected animals 


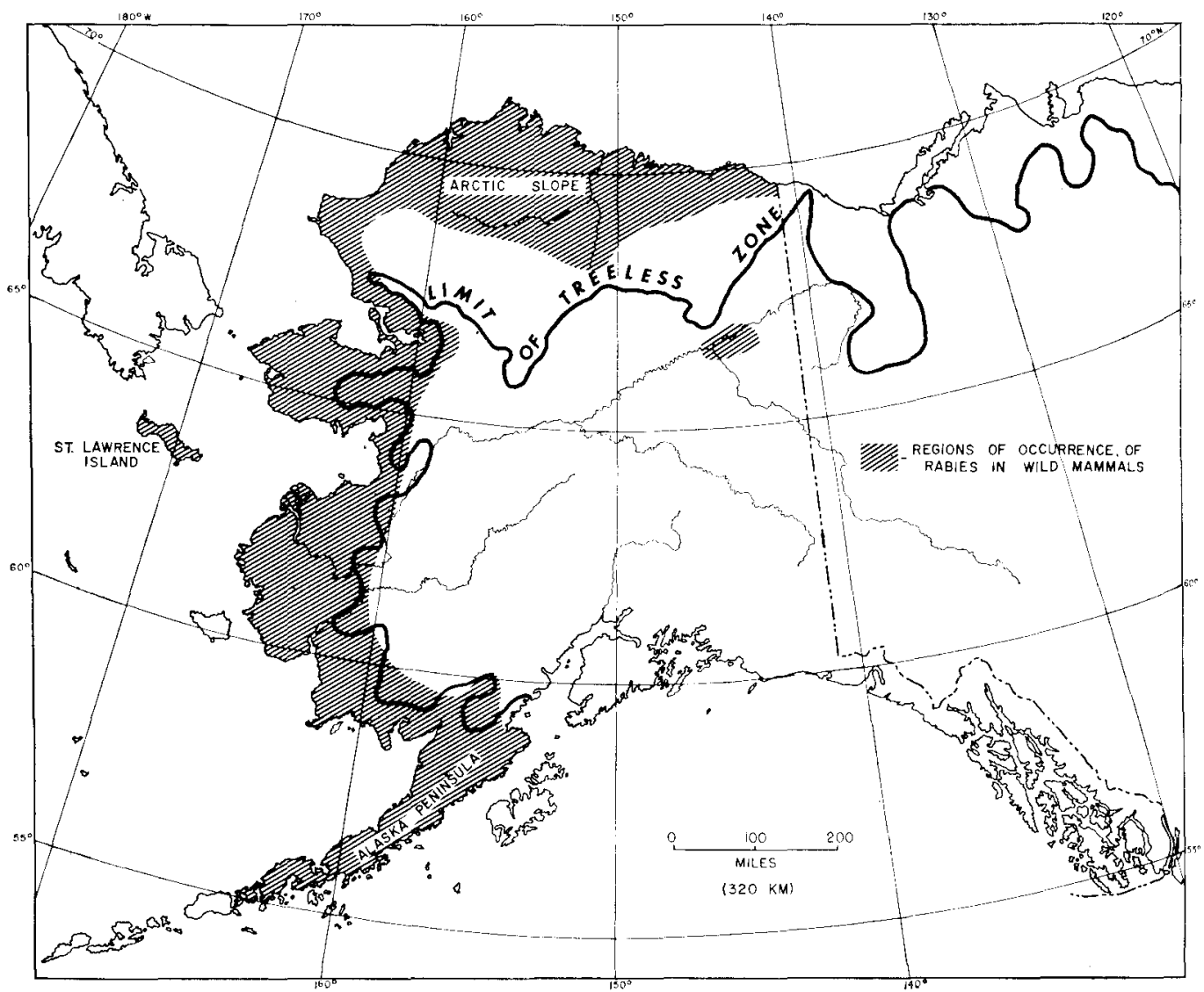

Fig 1.- Map of Alaska, showing regions (shaded) from which rabies has been reported in wild mammals.

Fig 2.- Recorded occurrence of rabies in foxes in relation to fluctuations in numbers of brown lemmings in the vicinity of Point Barrow, arctic Alaska.

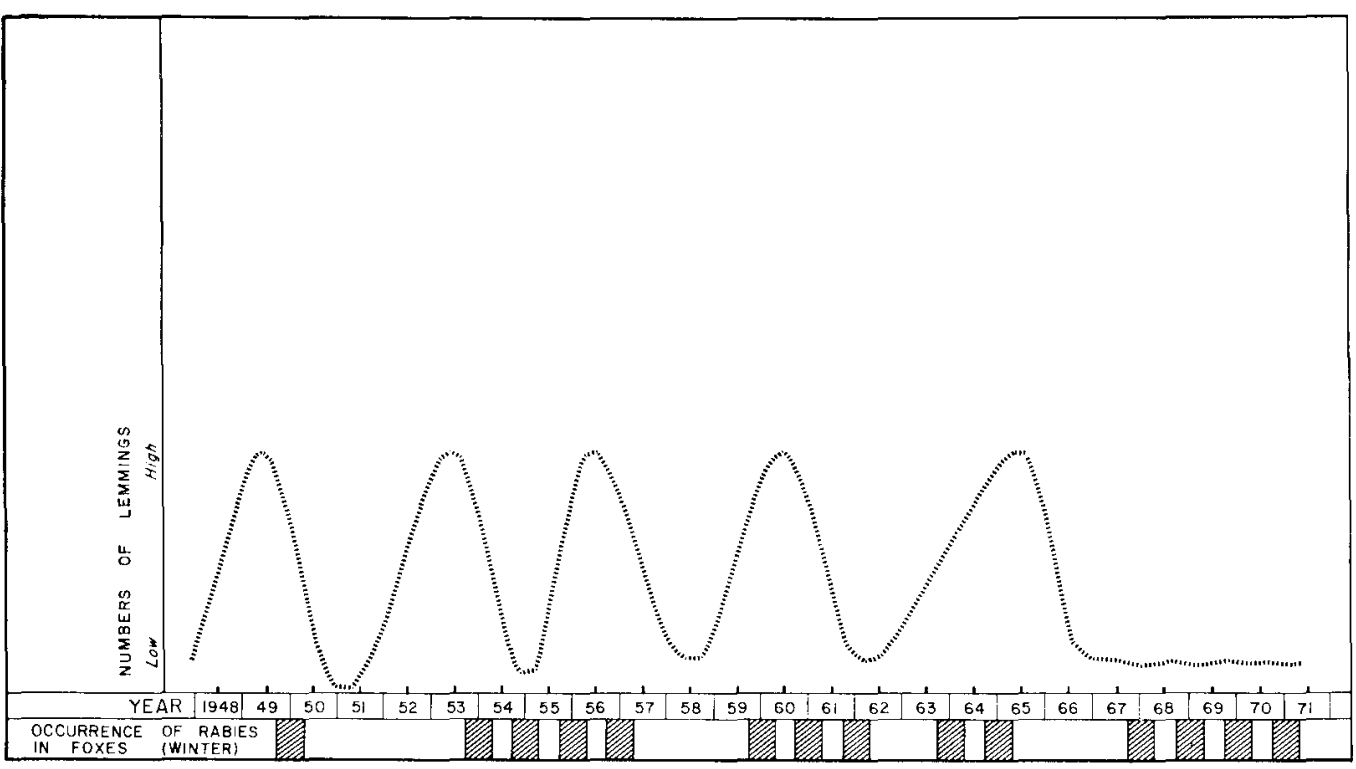

Arch Environ Health-Vol 25, Oct 1972 


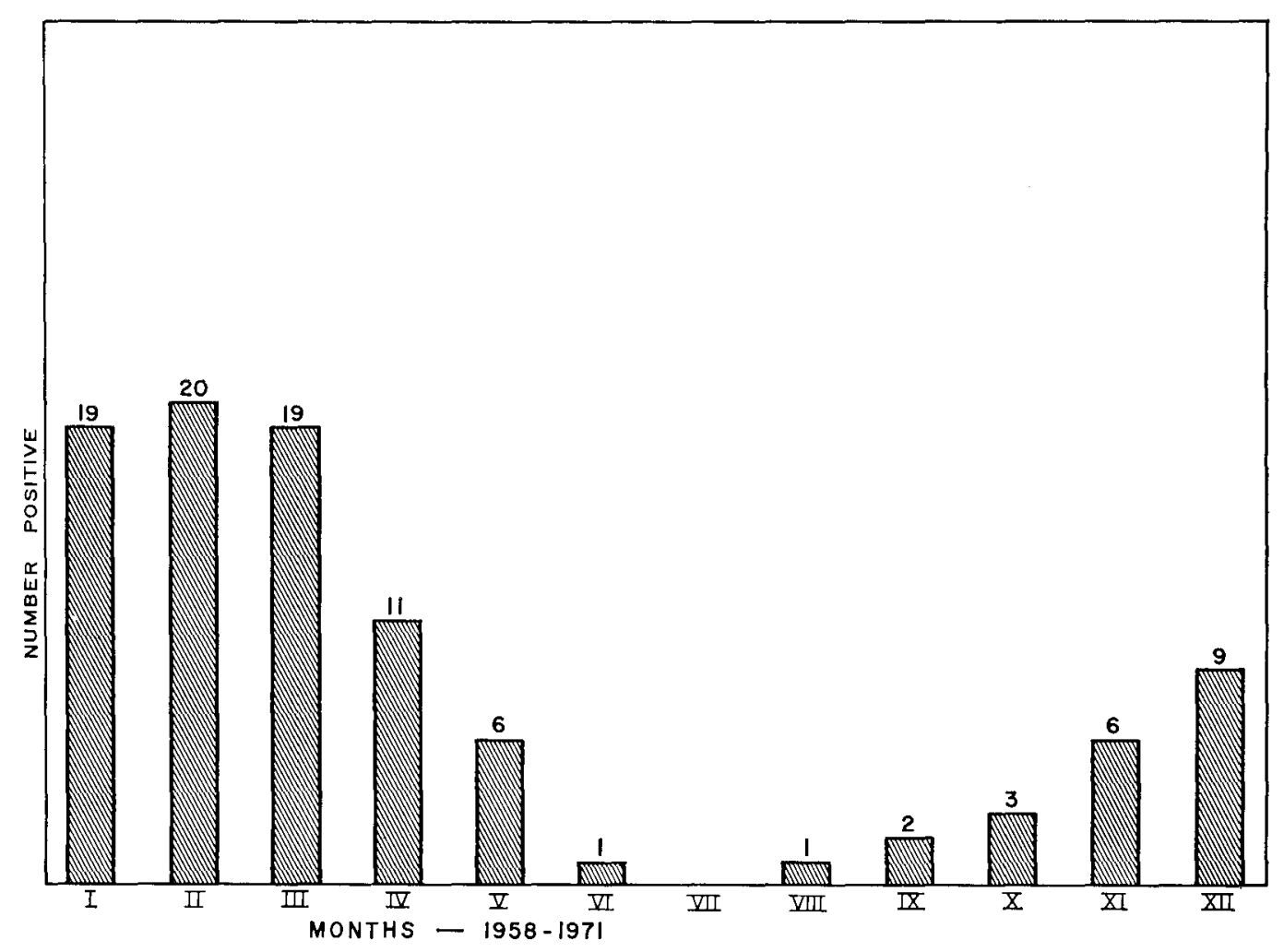

Fig 3.-Confirmed cases of rabies in red foxes, Vulpes vulpes, from the tundra zone of Alaska (see Fig 1) summarized by month (297 examined).

will survive the period of minimal intraspecific contact during spring and summer and provide a source of virus when conditions again become optimal for its transmission. In experimentally infected arctic foxes, we observed periods of incubation ranging from 20 days to six months. In experimentally infected foxes of both species, clinical signs of disease were evident for 24 to 48 hours preceding death. Titration of the salivary glands of such animals showed a range of $10^{-4}$ to $10^{-6}$ minimal lethal dose $e_{50}$.

We have no information indicating that canine animals might be aberrant hosts of rabies virus in the Arctic, nor that any other carnivores (including mustelids) have a significant role in the natural cycle. ${ }^{3}$ In contrast to findings in temperate regions of both Eurasia and North America, ${ }^{4-6}$ records of rabies virus from mustelids in the north are rare. Only in May 1971 was the virus isolated from a mustelid in Alaska. This animal, a river otter, Lutra canadensis (Schreber), was captured after it had attacked a dog on the Alaska Peninsula, where rabies was prevalent in red foxes.

Ermines, Mustela erminea $\mathbf{L}$, and mouse weasels, $M$ nivalis $\mathrm{L}$, are the only mustelids that occur commonly on the arctic slope, where their numbers are correlated with those of brown lemmings. A combination of factors favoring the survival and increase of these weasels on the arctic slope since 1965 resulted, by the winter of 1969 to 1970 , in the greatest density observed since at least 1949 (F. A. Pitelka, personal communication, May 6, 1971). Although rabies occurred in foxes in this region during each of the last four years, there was no evidence of the involvement of weasels. Three ermines that we infected experimentally died within 23 to 26 days, and none exhibited any unusual characteristics with respect to the disease.

On St. Lawrence Island, the depauperate mammalian fauna includes no mustelids. 7 There, outbreaks among arctic foxes usually become evident annually in late summer or autumn, long before the virus could be introduced by immigrant foxes arriving on the first incoming sea ice of winter (usually in December). The natural cycle of rabies has been investigated in the region of the Kanin Peninsula, in arctic Eurasia, ${ }^{8}$ and there also the arctic fox appeared to be the only important host of 


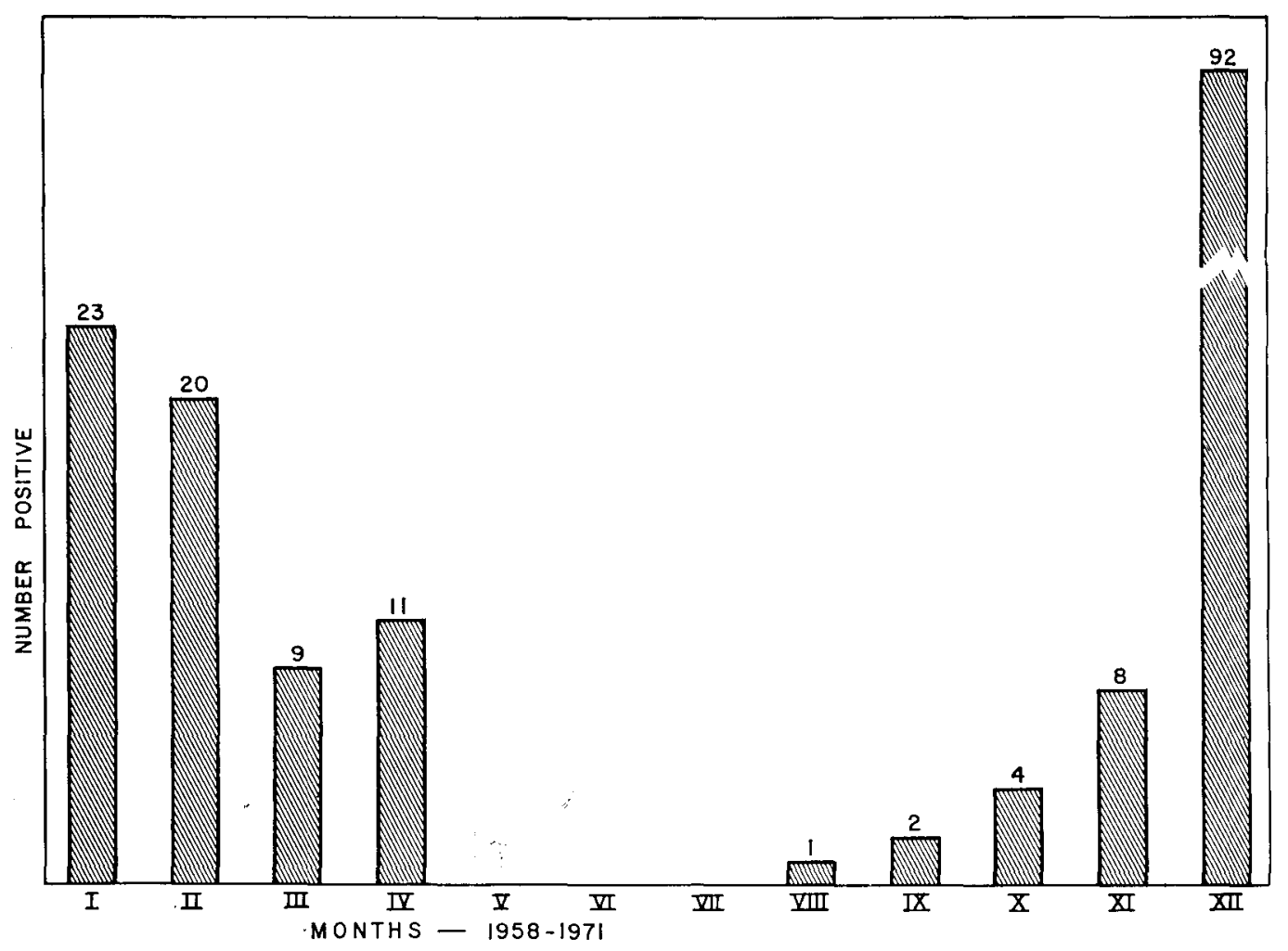

Fig 4.-Confirmed cases of rabies in arctic foxes, Alopex lagopus, from the tundra zone of Alaska (see Fig 1) (882 examined). Animals from St. Matthew Island are not included. The disproportionately large number for December partly reflects the greater availability of specimens during the trapping season.

the virus.

We conclude that rabies virus is indigenous at high latitudes, that its natural hosts in these regions are foxes (both Alopex and Vulpes), and that it is maintained in tundra-biocenoses by circulating continually in populations of foxes.

Little is known concerning other viral agents of zoonotic diseases in Alaska. Serological surveys indicate that arthropod-borne viruses are present.9 In 1971, California encephalitis virus (Snowshoe Hare strain) was isolated from both hares and mosquitoes in east-central Alaska (E. T. Feltz and K. M. Sommerman, unpublished data). Also isolated were other viruses still to be identified. As well, the relationship of the prevalence of such viruses to fluctuations in population density of the host, and the extent to which transmission is influenced by climatic factors affecting the vectors are yet to be investigated. Based on clinical and neuropathological findings, Japanese B encephalitis was reported as cause of death of a 10-month-old Indian child 10 ; the occurrence of the virus in Alaska has not been confirmed.

\section{Bacterial Diseases}

Only two natural-focal bacterial zoonoses are known to occur widely in Alaska. One, a strain of Brucella suis, designated biotype 4, has been found in Eurasia and North America in wild and domestic reindeer. After the occurrence in 1958 and 1959 of cases of human disease that were linked to the patients' contact with wild reindeer, studies were begun in which it was found that the organism is common in wild reindeer in arctic Alaska, and that relatively high rates of positive serological tests existed among Eskimos. ${ }^{11}$ We undertook experimental infections in small groups of reindeer from Nunivak Island (where the herds are ostensibly brucellosis-free). Females inoculated in autumn all aborted the following spring but produced living calves the next year. Serological titers attained maximum levels within one to two months after inoculation, and gradually declined thereafter. The natural relationships of the organism are poorly 
understood and probably are complex. Recent investigations ${ }^{12}$ indicate that both dogs and wild canids become infected in northern Alaska. In arctic Eurasia, the organism has been isolated from wolverine, Gulo gulo $\mathrm{L}$, wolf, and arctic fox; it is believed that carnivores become infected when they feed on carcasses of diseased reindeer. ${ }^{13,14}$

Infected reindeer introduced from Eurasia might have been the source of this organism in Alaska and northern Canada. However, it might also have spread with its host from the Amphiberingian region during postglacial time. Clinical findings compatible with brucellosis were not reported in the early literature concerning domestic reindeer in Alaska. ${ }^{15}$

The second, tularemia, is a disease of unusual interest in Alaska, because of the coexistence there of two strains of Francisella tularensis (holarctic and nearctic). ${ }^{16}$ The holarctic strain, reported from an arvicoline rodent, Microtus oeconomus (Pallas), may be responsible for subclinical infections in man, as evidenced by agglutinins in significant proportions of some populations of Indians and Eskimos. ${ }^{17,18}$ The more virulent nearctic strain was first recorded in Alaska in 1938 from ticks from varying hares. ${ }^{19}$ The affinities of the holarctic strain are presumably with the mammalian fauna of Amphiberingian origin, while the nearctic strain, with its vector the hare-tick, probably spread into northern North America with the varying hare during postglacial time.

In Alaska, such hares occur throughout the zones of coniferous forest and forest-tundra and when abundant may be found in shrubby vegetation extending along streams into treeless regions. Their populations undergo regular, high-amplitude fluctuations with a periodicity of about ten years. Cycles in different regions are not in phase. Ticks become locally numerous on hares for only two or three years before and during periods of maximum density. Thus, conditions seem to become optimal for circulation of the more virulent strain of $F$ tularensis in local foci at intervals of about seven to eight years. Whether other arthropods serve as vectors in Alaska has not been determined.

Pathogens of other groups, such as Leptospira and Chlamydia, have been recorded in natural foci in Alaska, ${ }^{20,21}$ but their bioce- notic relationships have not been investigated.

\section{Metazoan Parasites}

Alveolar hydatid disease of man is caused by a larval cestode, Echinococcus multilocularis Leuckart, 1863. Although occurring in diverse biocenoses in Eurasia, this cestode seems best adapted to existence in the zone of tundra, where the arctic fox and arvicoline rodents serve respectively as final and intermediate hosts throughout its extensive holarctic range. The implications of the predator-prey relationship between foxes and rodents are obvious, but the occurrence of this cestode at high latitudes, like that of rabies virus, seems to be influenced by more fundamental interactions of mammalian populations. Echinococcus multilocularis has not been recorded in mainland Alaska south of Nunivak Island, at latitude $60^{\circ} \mathrm{N}$. This parallel corresponds closely to the southern limit of the range of the arctic fox and seems also to approximate the southernmost limit of the region within which populations of rodents exhibit regular fluctuations.

Seasonal differences in rates of infection of foxes and rodents are correlated with the annual cycles of the mammals as well as with the extent to which foxes prey upon rodents. ${ }^{22}$ Maximum rates in the respective hosts are also influenced by regional differences in pattern of fluctuations in numbers of rodents. Where periodic peaks are followed by rapid decline to a very low density, as in brown lemmings on the arctic slope, ${ }^{23}$ rates of infection in both hosts remain low. As we observed in 1952 and 1953, a marked increase in rates of infection of lemmings by larvae of taeniid cestodes may occur if the density of rodents remains high for more than one year. In contrast, on St. Lawrence Island, voles, Microtus oecono$m u s$, exhibit less extreme fluctuations in numbers and usually remain numerous in optimal habitat. Under these conditions, rates of infection in both foxes and voles have been consistently high.

In establishing settlements in tundra biocenoses, man encroaches on, but does not extensively disrupt, naturally existing parasite-host assemblages. Embryophores scattered by foxes inhabiting the surrounding tundra seem to be unimportant as a source 
of infection for man, but dogs serve as synanthropic hosts, distributing large numbers of embryophores within the confines of such villages. Investigations have shown that hyperendemic foci may be produced when voles exist as commensals in settlements where dogs are numerous (F. H. Fay, unpublished data). Such is the case on St. Lawrence Island, where rates of $E$ multilocularis infection among the Eskimos are the highest recorded in Alaska.

Some other metazoan parasites that affect man at high latitudes have been shown to represent strains differing biologically from those occurring farther south. Examples include $E$ granulosus (Batsch, 1786), the larva of which causes cystic hydatid disease, ${ }^{24}$ and Trichinella spiralis (Owen, 1835), of which in Alaska both indigenous and introduced strains are found, the latter presumed to be of southern origin. ${ }^{25}$

The biocenoses in the northern regions, especially in the zone of tundra, are simple in composition and trophic patterns as compared with those of lower latitudes, although the advantage of such relative biotic simplicity is partly offset by the vastness of the landscape-zones and the effects of regional fluctuations in densities of mammalian populations. Biogeographic investigations have shown that the biota of northwestern North America consists of elements of both Amphiberingian (northern palearctic) and southern origin. It is becoming increasingly apparent that parasites (sensu lato) of vertebrates are similarly of diverse origins, compatible with patterns of dispersal of their hosts.

Frank A. Pitelka, PhD, Museum of Vertebrate Zoology, University of California, Berkeley, provided information and comments concerning fluctuations in mammalian populations near the arctic coast of Alaska. Kathryn M. Sommerman, PhD, Arctic Fealth Research Center, provided the information concerning biting flies in Alaska. Fleas collected by us in Alaska since 1950 have been identified by George P. Holland, PhD, Entomology Research Institute, Canada Department of Agriculture, Ottawa.

\section{References}

1. Holland GP: Faunal affinities of the fleas (Siphonaptera) of Alaska with an annotated list of species, in Gressitt JL (ed): Pacific Basin Biogeography. Honolulu, Bishop Museum Press, 1963, pp 45-63.

2. Lassen HCA: Paralytic human rabies in Greenland. Lancet 1:247-249, 1962.

3. Johnson HD: The ecological approach to the study of zoonotic diseases. $J$ Wildlife Dis 6:194-204, 1970.

4. Ulbrich F: Tollwut bei Mustelidae (Marderartige). Mh Vet Med 24:780-782, 1969

5. Hendricks SL, Seaton VA: Rabies in wild animals trapped for pelts. Bull Wildlife Dis Assoc 5:231-234, 1969.

6. Schnurrenberger PR, Martin RJ, Koch JM: Rabies in Illinois skunks. $J$ Amer Vet Med Assoc 157:1336-1342, 1970.

7. Rausch RL: On the land mammals of St. Lawrence Island, Alaska. Murrelet 34:18-26, 1953.

8. Kantorovich RA: Natural foci of a rabies-like infection in the far north. $J$ Hyg Epidem Microbiol Immunol 8:100-110, 1964.

9. Feltz ET, List-Young B, Ritter DG, et al: California encephalitis virus: Serological evidence of human infections in Alaska. Canad $J$ Microbiol 18:757-762, 1972.

10. Arthaud JB: Cause of death in 339 Alaskan natives as determined by autopsy. Arch Path 90:433-438, 1970.

11. Brody JA, Huntley B, Overfield TM, et al: Studies of human brucellosis in Alaska. $J$ Infect Dis 116:263-269, 1966.

12. Neiland KA: Rangiferine brucellosis in Alaskan canids. J Wildlife Dis 6:136-139, 1970.

13. Pinigin AF, Zabrodin VA: On the natural focality of brucellosis. Vestn Sel'Skokhoz Nauki 7:96-99, 1970.

14. Pinigin AF, Zabrodin VA, Nikulina VI: Bru- cellosis in the arctic fox. Krolikovod Zverovod 5:3940, 1970.

15. Hadwen S, Palmer LJ: Reindeer in Alaska, bulletin 1089. Dept of Agriculture, 1922.

16. Olsufjev NG: Taxonomy and characteristics of the genus Francisella Dorofeev, 1947. J Hyg Epidem 14:67-74, 1970.

17. Rausch RL, Huntley BE, Bridgens JG: Notes on Pasteurella tularensis isolated from a vole, $\mathrm{Mi}$ crotus oeconomus Pallas, in Alaska. Canad $J$ Microbiol 15:47-55, 1969.

18. Philip RN, Huntley B, Lackman DB, et al: Serologic and skin test evidence of tularemia infection among Alaskan Eskimos, Indians and Aleuts. J Infect $D$ is 110:220-230, 1962 .

19. Philip CB, Parker RR: Occurrence of tularaemia in the rabbit tick (Haemaphysalis leporis-palustris) in Alaska. Public Health Rep 53:574-575, 1938.

20. Rausch RL: Zoonotic diseases in the changing Arctic. Arch Environ Health 17:627-630, 1968.

21. Eddie B, Sladen WJI, Sladen BK, et al: Serologic studies and isolation of Bedsonia agents from northern fur seals on the Pribilof Islands. Amer J Epidem 84:405-410, 1966.

22. Fay FH, Rausch RL: The seasonal cycle of abundance of Echinococcus multilocularis in naturally infected arctic foxes. Proc Internat Congr Parasit 2:765-766, 1966.

23. Pitelka FA: Some aspects of population structure in the short-term cycle of the brown lemming in northern Alaska. Cold Springs Harbor Symposia on Quantitative Biol 22:237-251, 1957.

24. Wilson JF, Diddams AC, Rausch RL: Cystic hydatid disease in Alaska: A review of 101 autochthonous cases of Echinococcus granulosus infection. Amer Rev Resp Dis 98:1-15, 1968.

25. Rausch RL: Trichinosis in the Arctic, in Gould SE (ed): Trichinosis in Man and Animals. Springfield, III, Charles C Thomas Publisher, 1970, pp 348-373. 